\title{
EFFECTIVENESS OF THE ECHOENDOSCOPIC PUNCTURE IN THE DIAGNOSIS OF SOLID PANCREATIC MASS
}

\section{Efetividade da punção ecoendoscópica no diagnóstico de massa pancreática sólida}

\author{
Adriano Fernandes da SILVA, Eduardo Guimarães Hourneaux de MOURA, Everson Luiz de Almeida ARTIFON, \\ Paulo SAKAI, Fauze MALUF-FILHO, Sergio Eiji MATUGUMA, Dalton Marques CHAVES
}

ABCDDV/671

Silva AF, Moura EGH, Artifon ELA, Sakai P, Maluf-Filho F, Matuguma SE, Chaves DM. Effectiveness of the echoendoscopic puncture in the diagnosis of solid pancreatic mass. ABCD Arq Bras Cir Dig 2009;22(4):192-6

ABSTRACT - Background - Echoendoscopy is a mixed technique which adds the advantages of endoscopy to those of transabdominal ultrasonography through an endoscope with transductor in its distal extremity, allowing for the evaluation of the abdominal organs reached by the endoscope and in contact with the intestinal wall. Aim - To verify the positivity rate of the echoendoscopy with puncture with thin needle (EEPTN) or (EE-PAF) in solid pancreatic mass based on the technique used in the Gastrointestinal Endoscopy Unit of Hospital das Clínicas, University of São Paulo. Methods - Retrospective evaluation - cohort study - of 138 patients who were submitted to echoendoscopy through aspiration puncture between May 2004 and June 2007. The data were collected through the medical charts present in the medical files of Hospital das Clínicas (Clinical Hospital) of the University of São Paulo, having as inclusion criterion the presence of solid pancreatic mass in computerized tomography and as exclusion criterion the presence of non solid pancreatic tumor. The routine technique was the one used in the Gastrointestinal Endoscopy Unit focusing the following variables: mass characteristics (size, location, presence of peripancreatic lymph node, presence of lymph node in celiac trunk); number of punctures to obtain microfragment for cytology, and experience of the professional in charge. The equipment used was an echoendoscopy device model Olympus EUS (EYES) Exera EU - C60, with electronic sectorial transductor and 22 gauges Wilson-Cook needles. Results - Seventy six (55,4\%) male patients and 61 (44.5\%) female were enrolled. Age ranged from 16 to 87 years and means 59,9 years. The lesions were cephalic in 94 (68,1\%). Mass larger than $4 \mathrm{~cm}$ had a higher percentage of positivity reaching $40 \%$, but lesions smaller than $2 \mathrm{~cm}$ had a percentage of $43 \%$ of inconclusive. Microfragments were obtained in $100 \%$ of the positive cases and only $73,1 \%$ when negative $(\mathrm{P}=0,004)$. There was no statistic difference regarding the experience of the endoscopy professional. Only 80 patients had the number of punctures written down and it was noticed that there is better performance as the number of punctures was increased. The definitive histopathologycal diagnosis of pancreatic neoplasia occurred in only 41(29,7\%) patients. Conclusions - Regarding mass characteristics, when larger is the mass, larger is the positivity of the method; the location didn't correlate with higher positivity; when the lymph nodes were present, there was a tendency to positivity; concerning the number of punctures, the higher number, higher positivity; in relationship to the professional experience in endoscopy, there was no difference in the rate of positivity of the puncture of the solid pancreatic mass.

HEADINGS - Solid pancreatic mass. Echoendoscopy. Puncture.

\section{INTRODUCTION}

Adenocarcinoma represents $90 \%$ of the pancreatic neoplasias. In Brazil it corresponds to $2 \%$ of all kinds of cancers and is responsible for $4 \%$ of the total of cancer deaths ${ }^{18}$. The frequency of this neoplasia varies according to the age, being 10 cases $/ 100,000$ in the fourth decade and 116 cases $/ 100,000$ between 80 and 85 years old. In the USA approximately 37,000 new cases are diagnosed each year, which represents the fifth death cause from neoplasia in the male population ${ }^{19}$. The world incidence is estimated in 200,000 new cases per year.

The patients habitually present obstructive jaundice, weight loss, abdominal discomfort or pain at the moment of the diagnosis, which represent most of the time an ad-

From the University of São Paulo School of Medicine Department of Gastroenterology, Gastrointestinal Endoscopy Unit, São Paulo, SP, Brazil

Correspondência: Adriano Fernandes da Silva, e-mail: adrianofernandes7@gmail.com vanced stage of the disease and reserved prognosis. It is estimated that only $3.5 \%$ of them will survive five years after the diagnosis ${ }^{18}$ and this is due to the fast evaluation of the disease involving adjacent organs and early onset of metastasis which impede the surgical resection, the only real chance of cure. This condition justifies the search for complementary diagnostic methods such as echoendoscopy, which may diagnose this illness at an early stage.

Echoendoscopy, which started with DiMagno et al. ${ }^{10}$ in the USA, Hisnaga et al. ${ }^{15}$ in Japan and Strohm et al. ${ }^{28}$ in Germany, is a mixed technique which adds the advantages of endoscopy to those of transabdominal ultrasonography through an endoscope with transductor in its distal extremity, allowing for the evaluation of the abdominal organs reached by the endoscope and in contact with the intestinal wall. As of the 1990s, with Vilmann et al. ${ }^{29}$ there was a development of capacity of the endoscopy to perform biopsies through punctures, even in very small lesions diagnosed by tomography or magnetic resonance, even making it possible to stage these lesions locally. 
The indication of echoendoscopy through fine needle aspiration includes biopsies of lesions, mucosa and submucosa whose conventional endoscopy couldn't produce a diagnosis. This procedure is more commonly used in periintestinal structures such as lymph nodes and pancreatic masses, hepatic, adrenal gland and biliary duct. Therefore, it is an efficient method to evaluate solid masses in the pancreatic parenchyma, since it does not present gas or abdominal fat interposition. Many authors, including Gress et al. ${ }^{14}$, Eloubeidi et al. ${ }^{11}$ and Maluf F. ${ }^{24}$ report that endoscopy shows sensitivity between 80 and $90 \%$ and specificity near $100 \%$ when detecting pancreatic solid lesions. Agarwal et al. ${ }^{1}$ claim that the absence of focal pancreatic value means absence of pancreatic lesion to echoendoscopy.

Some complication may occur and the most frequent are pancreatitis and bleeding, although with incidence between 1 and $4 \%$ and contamination of the trajectory area of neoplasia puncture, which had its first case described by Paquin et al. ${ }^{26}$.

There are several studies comparing the pancreatic mass diagnostic method. Wiersema ${ }^{30}$ compared echoendoscopy with computerized tomography and observed higher sensitivity and specificity in the first one. DeWitt et al. ${ }^{9}$ evaluated with higher sensitivity and specificity the presence of regional lymph nodes. Soriano et al. ${ }^{27}$, in their turn, presented advantage of tomography as it diagnoses metastasis from a distance. However, it would be better to evaluate them with complementary exams to stage pancreatic cancer.

The retrograde endoscopic colangiopancreatography (RECP) is also used as a method to diagnose these biliary pancreatic lesions, making it possible to obtain cytological brush to anatomic pathologic analysis. However, it presents an incidence of complication which can not be disregarded as well as low sensitivity and accuracy (33.3\% and 46.7 $\%$ respectively).

On comparing echoendoscopy with magnetic resonance, Muller et al. ${ }^{25}$ presented sensitivity of $94 \%$ to echoendoscopy versus $84 \%$ on it in lesions smaller than $3 \mathrm{~cm}$ and specificity near $100 \%$ to both methods. Echoendoscopy presents an advantage as it allows diagnostic puncture.

Levy $^{21,22}$, as well as Wiersema ${ }^{30}$ highlight the fact that echoendoscopy is a method with high sensitivity and specificity to identify pancreatic mass and it presents higher costbenefit ratio if compared to the methods described above.

This study was proposed in order to evaluate the impact of this methodology in the diagnosis of solid pancreatic mass and the evaluation of the results in this institution.

\section{METHODS}

This study involves the retrospective cohort evaluation of 138 patients who underwent echoendoscopy through fine needle aspiration puncture (EE - FNAP), having as inclusion criterion the presence of solid pancreatic mass in computerized tomography.

The interest variables of this research were: characteristics of mass (size, location, presence of peripancreatic lymph nodes, presence of lymph nodes in celiac trunk); number of punctures to obtain microfragment and cytological material and experience of the professional who executed the procedures.

The exclusion criterion was the presence of non solid pancreatic tumor.

The research data were collected through the patient's records existing in the medical files of the Hospital das Clínicas of the University of São Paulo in the period between May 2004 and June 2007.

In the EE - FNAP procedure an Olympus echoendoscope, model Olympus EUS (EYS) Exera EU-60 with electronic sectorial transductor was used. This appliance is connected to an Olympus Exera CLV-160 processor. The needles used in the punctures were Wilson - Cook 22 gauges.

The work with the blades used the coloring technique known as Papanicolau and the fragments were set in blocks using the technique known as Cell-block. The pathologic exam followed the usual routine of the Pathology Service of the Pathologic Anatomy Department of the University. Five results were standardized in the Service: 1 - positive, included all forms of solid neoplasias; 2 - suspected, presence of cellular or architectural pattern suggesting neoplasia; 3 - undetermined, presence of representative material but which did not fit any classification of neoplasia; 4 - negative, enough material and without signs of malignancy in the sample; 5 -inconclusive, little representative material or not enough material for any diagnostic analysis.

\section{RESULTS}

Setenty six (55.47\%) were males and $61(44.53 \%)$ females. Their age ranged between 16 and 87 years old, with average of 59.9 and median 51.5 years.

It can be observed on Table 1 that the percentage of inconclusive diagnosis $(43.2 \%)$ tends to be higher for tumors with smaller solid pancreatic mass (up to $2 \mathrm{~cm}$ ). This same tendency is noticed in negative results $(32.4$ $\%)$. On the other hand, there is a tendency to increase the positivity percentage as the pancreatic mass increases. For masses between $4 \mathrm{~cm}$ and $6 \mathrm{~cm}$ the positivity percentage reached $40.0 \%$ (Figure1).

The qui-square test which was employed with value 0.118 , did not detect association between the variables

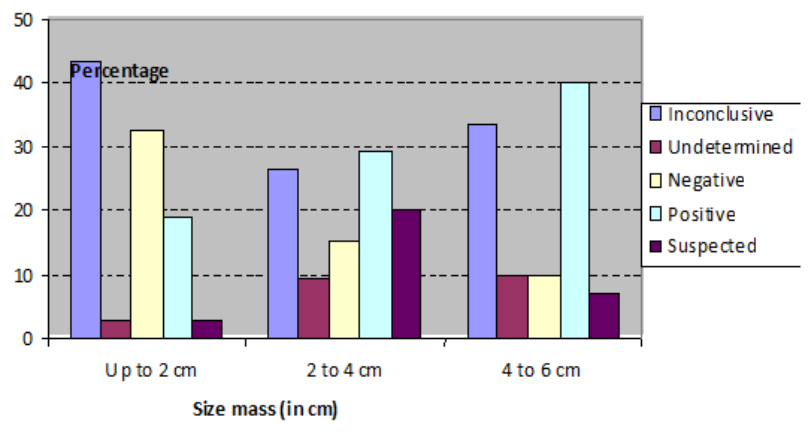

FIGURE 1 - Diagnosis percentage and mass size 
TABLE 1 - Diagnosis percentage (\%) and mass size*

\begin{tabular}{lcccc}
\hline \multirow{2}{*}{ Diagnosis } & \multicolumn{3}{c}{$\mathbf{S}$ : Mass size (cm)* } & \multirow{2}{*}{ Total } \\
\cline { 2 - 4 } Inconclusive & $\mathbf{S} \leq \mathbf{2}$ & $\mathbf{2}<\mathbf{S} \leq \mathbf{4}$ & $\mathbf{4}<\mathbf{S} \leq \mathbf{6}$ & \\
\hline Undetermined & 16 & 17 & 10 & 43 \\
& $(43,2)$ & $(26,2)$ & $(33,3)$ & $(32,6)$ \\
\hline Negative & 1 & 6 & 3 & 10 \\
& $(2,7)$ & $(9,2)$ & $(10,0)$ & $(7,6)$ \\
\hline Positive & 12 & 10 & 3 & 25 \\
& $(32,4)$ & $(15,4)$ & $(10,0)$ & $(18,9)$ \\
\hline Suspected & 7 & 19 & 12 & 38 \\
& $(18,9)$ & $(29,2)$ & $(40,0)$ & $(28,8)$ \\
\hline Total & $(2,7)$ & $(20,0)$ & $(6,7)$ & $(12,1)$ \\
& 37 & 65 & 30 & 132 \\
& $(100,0)$ & $(100,0)$ & $(100,0)$ & $(100,0)$ \\
\hline
\end{tabular}

Value $\mathrm{P}=0,012 *$ The size of six tumors was not measured.

peripancreatic lymph nodes and diagnosis. The qui-square test with value 0.394 detected association between lymph nodes in the celiac trunk and diagnosis.

The definite neoplasia pathologic diagnosis for pancreatic neoplasia occurred only in 42 patients $(29.71 \%$ - Figure 2 ), being the adenocarcinoma responsible for $86.37 \%$, followed by the endocrine tumor (13.57\%).

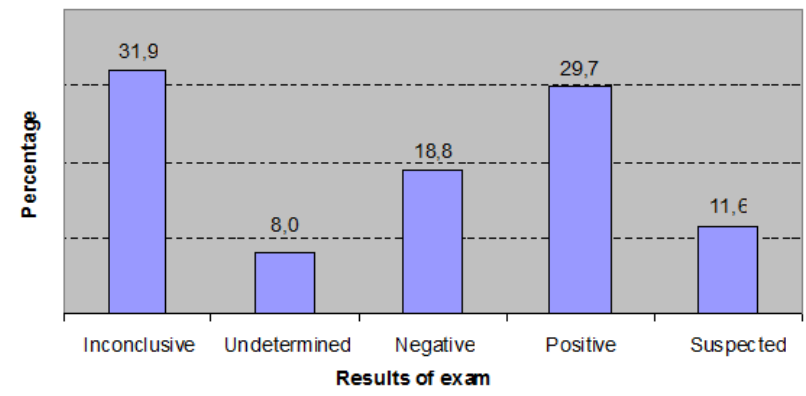

FIGURE 2 - Pathologic aspects for malignancy

The size of the sample was not sufficient to verify the existence of association between the number of punctures and the diagnosis. However, there is a tendency of higher detection of positive diagnosis as the number of punctures increases (Table 2 and Figure 3).

TABLE 2 - Frequency and percentage distribution of diagnosis and the number of punctures

\begin{tabular}{lccccc}
\hline \multirow{2}{*}{ Diagnosis } & \multicolumn{4}{c}{ Number of punctures } & \multirow{2}{*}{ Total } \\
\cline { 2 - 5 } & $\mathbf{1}$ & $\mathbf{2}$ & $\mathbf{3}$ & $\mathbf{4}$ & \\
\hline Inconclusive & 2 & 10 & 7 & 2 & 21 \\
& $(25,0)$ & $(29,4)$ & $(31,8)$ & $(12,5)$ & $(26,3)$ \\
\hline Undetermined & 1 & 3 & 0 & 3 & 7 \\
& $(12,5)$ & $(8,8)$ & $(0,0)$ & $(18,8)$ & $(8,8)$ \\
\hline Negative & 3 & 7 & 5 & 2 & 17 \\
& $(37,5)$ & $(20,6)$ & $(22,7)$ & $(12,5)$ & $(21,3)$ \\
\hline Positive & 2 & 8 & 8 & 6 & 24 \\
& $(25,0)$ & $(23,5)$ & $(36,4)$ & $(37,5)$ & $(30,0)$ \\
\hline Suspected & 0 & 6 & 2 & 3 & 11 \\
& $(0,0)$ & $(17,7)$ & $(9,1)$ & $(18,8)$ & $(13,8)$ \\
\hline Total & 8 & 34 & 22 & 16 & 80 \\
& $(100,0)$ & $(100,0)$ & $(100,0)$ & $(100,0)$ & $(100,0)$ \\
\hline
\end{tabular}

Value P: insufficient sample size

Note: 58 puncture numbers were not possible to be reached

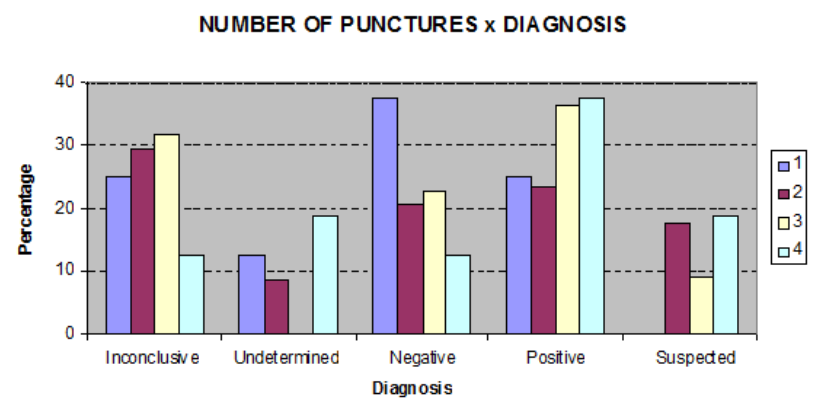

FIGURE 3 - Frequency and percentage distribution of diagnosis and the number of punctures

\section{DISCUSSION}

In this institution either the helical tomography or magnetic resonance is determined as a first exam used in the investigation of solid pancreatic mass, such as the algorithm proposed by $\mathrm{Chaya}^{8}$, followed by the of echoendoscopy to evaluate the resectability of the lesion (Figure 4).

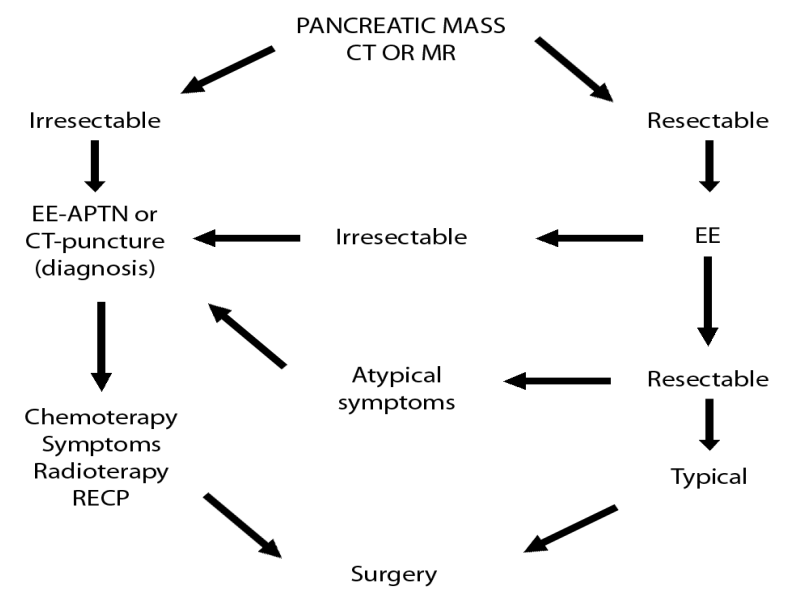

Source: Chaya C, Nealon WH, Bhutani MS. EUS or percutaneous CT/US-guided FNA for suspected pancreatic cancer: when tissue is the issue. Gastrointest Endosc. 2006 Jun;63(7):976-8

$\mathrm{CT}=$ computerized tomography; $\mathrm{MR}=$ magnetic resonance; $\mathrm{EE}=$ echoendoscopy; $\mathrm{EE}-\mathrm{FNA}$ $=$ echoendoscopy through fine needle aspiration; $\mathrm{RECP}=$ retrograde endoscopic colagiopancreatography

FIGURE 4 - Evalutation of lesion resectability

The initial echoendoscopy was able to detect $96 \%$ of the cases of pancreatic mass ( $23 \%$ of which not seen in the tomography) and was able to perform puncture, leading to a cytological diagnosis of malignancy in more than $95 \%$ of the cases. It presented sensitivity of $93 \%$ and specificity of $100 \%$ in patients with pancreatic mass of suspected tumor, with puncture guided by tomography or cytological brush in the retrograde endoscopic colagiopancreatography. Both results were negative $\mathrm{e}^{14,30}$.

Pancreatic neoplasia is more frequent in men, which obtained higher positivity in this study, and in older age. It was therefore suitable to the statistic data found in medical world literature.

Regarding mass size, a recent study of Agarwal et al. ${ }^{2}$ showed increase of resectability of solid pancreatic masses 
equal to or smaller than $20 \mathrm{~mm}$ (10 in $12-83 \%$ ), while in masses equal to or bigger than $30 \mathrm{~mm}$, only $7 \%$ (2 in 27). In Brazil, Ardengh et al. ${ }^{3}$ presented a study with 180 patients having lesions smaller than $3 \mathrm{~cm}$ with sensitivity of 82.4 $\%$ and specificity of $98.4 \%$. Hunt and Faigel ${ }^{17}$, reviewing four studies including 164 patients presented sensitivity of $91 \%$ and specificity of $100 \%$. This is much superior to what was found in this study, where approximately $50 \%$ of these lesions were inconclusive to the puncture.

The preferential location was the cephalic portion, also presenting correspondence with the medical literature, what did not favored the positivity, although in a bigger sample this could be presented as a factor of positivity improvement.

In this study it was not possible to characterize the lymph nodes, but it was possible to either detect their presence or not. In medical literature the characteristic description is frequent, and in addition to this their puncture is also carried on, obtaining positivity on average of $90 \%$ and sensitivity of $100 \% \%^{5,6,7,13}$.

The simple presence of these lymph nodes in peripancreatic position meant an increase of puncture positivity, what indirectly suggests a more advanced stage. As to obtaining biopsies, it is clear that this influences positivity, that is, when the fragment is obtained, the positivity increases. Ho, et al..$^{21}$ observed the effectiveness of the EE - FNAP in a retrospective study, dividing 10 years of experience with the method into precocious (1996-2000) and late (2001-2005). As a result, there was an increase of precise diagnosis of 40 $\%$ to $95 \%$, due to the increase in accuracy of cytological diagnosis and mainly due to the increase in obtaining biopsies (microfragments). This is also observed in medical literature. An example of this is when Levy and Wiersema ${ }^{21,22}$ compared two kinds of needles (a 19 gauge Trucut) and the conventional needle. As a surprise a best result was found when the conventional needle was used. This is because the conventional needle is easier to handle especially in a duodenal position. Although the institution where the study was carried on adopts the use of the 22-gauge needle - as described in method -, this was not relevant enough to reflect higher positivity rates. Wittmann et al. ${ }^{31}$ conducted a study associating the two needles and obtained higher sensitivity and specificity. The collection of material to make the blades is important but in this study it presented low performance, which is perhaps explained by the use of the Papanicolau technique and Cell-block, because in Brazil Maluf-Filho et al. ${ }^{23}$ presented sensitivity of $95 \%$ and specificity of $100 \%$ using the agar coloring technique.

Anyway, the same kind of pathologic classification of the literature was used, that is, the findings were grouped into categories, not classifying for example the specific kinds of tumors, what permitted the comparison between the findings in several different services ${ }^{4}$. In two cases, the pathology groups put undetermined and inconclusive because they understood that in these two cases the method did not define the pathology in question ${ }^{11}$. In fact this same author suggests that a new EE - FNAP exam should be made when the results obtained are undetermined or negative, but with high clinical suspicion of cancer, and presented a study with accuracy of $84 \%$ in this diagnostic confirmation. When this situation of undetermined or negative with strong clinical suspicion of neoplasia persists, despite the image methods such as EE - FNAP, tomography and magnetic resonance are employed, Eloubeidi et al. ${ }^{11}$ suggests surgical exploration.

Some flaws might be occurring to explain the service's poor performance: low number of punctures, inadequate preparation of material, old fashioned technique employed in the material coloring, absence of pathologist during the procedure, and the experience of the endoscopy professional.

The number of punctures performed may be the main responsible for the positivity's poor performance. LeBlanc, Ciaccia e Al-Assi ${ }^{20}$ determine a minimum of seven punctures of the lesion and five punctures when there is presence of ganglions, considering that the service does not count on a pathologist during the procedure. Erickson, Sayage-Rabie e Beissner ${ }^{13}$ already called attention to this fact at the first time they researched the influence of the number of punctures performed.

The fact that such materials are collected and prepared by another endoscopist or an intern contributes negatively to a good blade preparation. The preparation of the material using the agar coloring technique presented by Maluf -Filho et al. ${ }^{23}$, represented sensitivity of $95 \%$ even with the absence of a pathologist. Eloubeidi et al. ${ }^{11}$ in their turn refer to the presence of a pathologist during the procedure as compulsory. He is the one who determines the moment to stop collecting material, that is, the pathologist determines if the material is adequate. In a study published in 2003, these authors managed to have sensitivity rates of $98 \%$ and the number of punctures varied from one to 11 . The experience of the professional was also evaluated. However, because it considers the basic guidelines established by the American Gastrointestinal Endoscopy Society (ASGE, 2001), even if it is not compulsory in Brazil, it is believed that it was not a relevant factor to the low rate of positivity compared with the one in literature.

Other factors pointed out by Eloubeidi et al. ${ }^{12}$ such as co-existence of pancreatitis, technical difficulty of puncture, tumor necrosis, interpathologist variation may lead to flaws in the diagnosis. These flaws show the direction to be followed to improve the service provided. After all, this exam is of utter importance in the diagnosis and in therapeutics, and even nowadays it represents high cost considering the low performance observed if compared to the one demonstrated in medical literature.

\section{CONCLUSIONS}

Regarding mass characteristics, when larger is the mass, larger is the positivity of the method; the location didn't correlate with higher positivity; when the lymph nodes were present, there was a tendency to positivity; concerning the number of punctures, the higher number, higher positivity; in relationship to the professional experience in endoscopy, there was no difference in the rate of positivity of the puncture of the solid pancreatic mass. 
Silva AF, Moura EGH, Artifon ELA, Sakai P, Maluf-Filho F, Matuguma SE, Chaves DM. Efetividade da punção ecoendoscópica no diagnóstico de massa pancreática sólida. ABCD Arq Bras Cir Dig 2009;22(4):192-6

RESUMO - Racional - Ecoendoscopia é técnica mista que adiciona as vantagens da endoscopia àquelas da ecografia, somente que o procedimento ecográfico é realizado do interior dos órgãos para fora deles, no sentido centrífugo. Objetivo - Verificar a positividade da ecoendoscopia na punção com agulhas (EEPTN) ou (EE-PAF) em tumores sólidos pancreáticos baseados na técnica utilizada pelo Serviço de Endoscopia Digestiva do Hospital de Clínicas da Universidade de São Paulo. Métodos - Cohorte retrospectiva de 138 pacientes que realizaram ecoendoscopia com punção aspirativa por agulha fina (EE-PAAF) no período de maio de 2004 a junho de 2007. Os dados foram coletados por meio de consulta aos prontuários, constantes do arquivo médico. O critério de inclusão foi a presença de massa pancreática sólida à tomografia computadorizada e o critério de exclusão a presença de tumor pancreático não sólido. Foram utilizadas as seguintes variáveis: característica da massa (tamanho, localização, presença de linfonodo peripancreático, presença de linfonodo em tronco celíaco); número de punções para obtenção de microfragmento; citologia e experiência do profissional executante. O aparelho utilizado foi um ecoendoscópio da marca Olympus, modelo OLYMPUS EUS (EYS) EXERA EU-C60, com transdutor setorial eletrônico e agulhas de 22 gauges da marca Boston Scientific. Resultados - Setenta e seis (55,4 \%) deles eram do sexo masculino e $61(44,5 \%)$ do feminino. A idade variou de 16 a 87 anos, com média de 59,9 anos. As lesões foram cefálicas em 94 (68,1 \%) dos casos. Massas maiores que $4 \mathrm{~cm}$ tiveram percentual de positividade maior, chegando a $40 \%$, mas as lesões menores que $2 \mathrm{~cm}$ obtiveram percentual de $43 \%$ de inconclusivo. A obtenção de microfragmentos foi conseguida em $100 \%$ dos casos positivos e apenas $73,1 \%$, quando negativo $(\mathrm{P}=0,004)$. Não houve diferença estatística em relação à experiência do endoscopista. Apenas 80 pacientes tiveram anotado o número de punções e notou-se que existe melhor desempenho quanto maior for o número delas. O diagnóstico anatomopatológico definitivo de neoplasia pancreática ocorreu em apenas 41 (29,7 \%) indivíduos. Conclusões - Em relação às características da massa, quanto maior ela era maior a positividade do método; a localização não correlacionou com maior positividade; há tendência de positividade quando presentes os linfonodos peripancreáticos; em relação ao número de punções, quanto maior o número delas, maior a positividade do método; em relação à experiência do profissional, não houve diferença no índice de positividade da punção da massa pancreática sólida.

DESCRITORES - Massa pancreática sólida. Ecoendoscopia. Punção.

\section{REFERENCES}

1. Agarwal B, Abu-Hamda E, Molke KL, Correa AM, Ho L. Endoscopic ultrasoundguided fine needle aspiration and multidetector spiral CT in the diagnosis of pancreatic cancer. Am J Gastroenterol. 2004 May;99(5):844-50.

2. Agarwal B, Correa AM, Ho L. Survival in pancreatic carcinoma based on tumor size. Pancreas. 2008 Jan;36(1):e15-20.

3. Ardengh JC, Lopes CV, de Lima LF, de Oliveira JR, Venco F, Santo GC, Modena JL. Diagnosis of pancreatic tumors by endoscopic ultrasound-guided fine-needle aspiration. World J Gastroenterol. 2007 Jun 14;13(22):3112-6.

4. Bardales RH, Stelow EB, Mallery S, Lai R, Stanley MW. Review of endoscopic ultrasound-guided fine-needle aspiration cytology. Diagn Cytopathol. 2006 Feb;34(2):140-75.

5. Bhutani MS, Hawes RH, Hoffman BJ. A comparison of the accuracy of echo features during endoscopic ultrasound (EUS) and EUS-guided fine-needle aspiration for diagnosis of malignant lymph node invasion. Gastrointest Endosc. 1997 Jun;45(6):474-9.

6. Binmoeller KF, Thul R, Rathod V, Henke P, Brand B, Jabusch HC, Soehendra $\mathrm{N}$. Endoscopic ultrasound-guided, 18-gauge, fine needle aspiration biopsy of the pancreas using a $2.8 \mathrm{~mm}$ channel convex array echoendoscope. Gastrointest Endosc. 1998 Feb;47(2):121-7.

7. Chang KJ, Nguyen P, Erickson RA, Durbin TE, Katz KD. The clinical utility of endoscopic ultrasound-guided fine-needle aspiration in the diagnosis and staging of pancreatic carcinoma Gastrointest Endosc. 1997 May;45(5):387-93.

8. Chaya C, Nealon WH, Bhutani MS. EUS or percutaneous CT/US-guided FNA for suspected pancreatic cancer: when tissue is the issue. Gastrointest Endosc. 2006 Jun;63(7):976-8.

9. DeWitt J, Devereaux B, Chriswell M, McGreevy K, Howard T, Imperiale TF, Ciaccia D, Lane KA, Maglinte D, Kopecky K, LeBlanc J, McHenry L, Madura J, Aisen A, Cramer H, Cummings O, Sherman S. Comparison of endoscopic ultrasonography and multidetector computed tomography for detecting and staging pancreatic cancer. Ann Intern Med. 2004 Nov 16;141(10):753-63.

10. DiMagno EP, Buxton JL, Regan PT, Hattery RR, Wilson DA, Suarez JR, Green PS. Ultrasonic endoscope. Lancet. 1980 Mar 22;1(8169):629-31.

11. Eloubeidi MA, Chen VK, Eltoum IA, Jhala D, Chhieng DC, Jhala N, Vickers SM, Wilcox CM. Endoscopic ultrasound-guided fine needle aspiration biopsy of patients with suspected pancreatic cancer: diagnostic accuracy and acute and 30-day complications. Am J Gastroenterol. 2003 Dec;98(12):2663-8.

12. Eloubeidi MA, Varadarajulu S, Desai S, Shirley R, Heslin MJ, Mehra M, Arnoletti JP, Eltoum I, Wilcox CM, Vickers SM. A prospective evaluation of an algorithm incorporating routine preoperative endoscopic ultrasound-guided fine needle aspiration in suspected pancreatic cancer. J Gastrointest Surg. 2007 Jul;11(7):813-9.

13. Erickson RA, Sayage-Rabie L, Beissner RS. Factors predicting the number of EUSguided fine-needle passes for diagnosis of pancreatic malignancies. Gastrointest Endosc. 2000 Feb;51(2):184-90.

14. Gress F, Gottlieb K, Sherman S, Lehman G. Endoscopic ultrasonography-guided fine-needle aspiration biopsy of suspected pancreatic cancer. Ann Intern Med. 2001 Mar 20;134(6):459-64

15. Hisanaga K, Hisanaga A, Nagata K, Ichie Y. High speed rotating scanner for transgastric sonography. AJR Am J Roentgenol. 1980 Sep;135(3):627-9.

16. Ho JM, Darcy SJ, Eysselein VE, Venegas R, French SW, Stabile BE. Evolution of fine needle aspiration cytology in the accurate diagnosis of pancreatic neoplasms. Am Surg. 2007 Oct;73(10):941-4.
17. Hunt GC, Faigel DO. Assessment of EUS for diagnosing, staging, and determining resectability of pancreatic cancer: a review. Gastrointest Endosc. 2002 Feb;55(2):232-7.

18. INCA. Incidência de câncer no Brasil: estimativa 2008. Brasília: Ministério da Saúde, 2007. Disponível em: $<$ http://www.inca.gov.br/estimativa/2008/>. Acesso em: 5 Jan. 2008.

19. Jemal A, Siegel R, Ward E, Murray T, Xu J, Thun MJ. Cancer statistics, 2007. CA Cancer J Clin. 2007 Jan-Feb;57(1):43-66.

20. LeBlanc JK, Ciaccia D, Al-Assi MT, McGrath K, Imperiale T, Tao LC, Vallery S, DeWitt J, Sherman S, Collins E. Optimal number of EUS-guided fine needle passes needed to obtain a correct diagnosis. Gastrointest Endosc. 2004Apr;59(4):475-81

21. Levy MJ, Wiersema MJ. EUS-guided Trucut biopsy. Gastrointest Endosc. 2005 Sep;62(3):417-26.

22. Levy MJ, Wiersema MJ. Pancreatic neoplasms. Gastrointest Endosc Clin N Am. 2005 Jan; 15(1):117-42.

23. Maluf-Filho F, Kumar A, Gerhardt R, Kubrusly M, Sakai P, Hondo F, Matuguma SE, Artifon E, Monteiro da Cunha JE, César Machado MC, Ishioka S, Forero E. Kras mutation analysis of fine needle aspirate under EUS guidance facilitates risk stratification of patients with pancreatic mass. J Clin Gastroenterol. 2007 Nov-Dec;41(10):906-10.

24. Maluf-Filho F, Sakai P, Ishioka S. Estado atual da ecoendoscopia. G.E.D 1998; 17:22-6.

25. Müller MF, Meyenberger C, Bertschinger P, Schaer R, Marincek B. Pancreatic tumors: evaluation with endoscopic US, CT, and MR imaging. Radiology. 1994 Mar;190(3):745-51.

26. Paquin SC, Gariépy G, Lepanto L, Bourdages R, Raymond G, Sahai AV. A first report of tumor seeding because of EUS-guided FNA of a pancreatic adenocarcinoma. Gastrointest Endosc. 2005 Apr;61(4):610-1.

27. Soriano A, Castells A, Ayuso C, Ayuso JR, de Caralt MT, Ginès MA, Real MI, Gilabert R, Quintó L, Trilla A, Feu F, Montanyà X, Fernández-Cruz L, Navarro $\mathrm{S}$. Preoperative staging and tumor resectability assessment of pancreatic cancer: prospective study comparing endoscopic ultrasonography, helical computed tomography, magnetic resonance imaging, and angiography. Am J Gastroenterol. 2004 Mar;99(3):492-501.

28. Strohm WD, Phillip J, Hagenmüller F, Classen M. Ultrasonic tomography by means of an ultrasonic fiberendoscope. Endoscopy. $1980 \mathrm{Sep}$;12(5):241-4.

29. Vilmann P, Jacobsen GK, Henriksen FW, Hancke S. Endoscopic ultrasonography with guided fine needle aspiration biopsy in pancreatic disease. Gastrointest Endosc. 1992 Mar-Apr;38(2):172-3.

30. Wiersema MJ. Accuracy of endoscopic ultrasound in diagnosing and staging pancreatic carcinoma. Pancreatology. 2001;1(6):625-32.

31. Wittmann J, Kocjan G, Sgouros SN, Deheragoda M, Pereira SP. Endoscopic ultrasound-guided tissue sampling by combined fine needle aspiration and trucut needle biopsy: a prospective study. Cytopathology. 2006 Feb;17(1):27-33.

Fonte de financiamento: não há Conflito de interesse: não há Recebido para publicação:23/07/2009 Aceito para publicação: 14/10/2009 